\title{
COMPARATIVE ASSESSMENT AND FEASIBILITY ANALYSIS OF NATURAL DYE SOURCES FOR COMMERCIAL APPLICATION
}

\author{
M.Anandhan ${ }^{1}$ \\ ${ }^{I}$ Department of Mechanical Engineering, Mepco schlenk Engineering college, Sivakasi, India
}

\begin{abstract}
Natural dyes extracted from plants are potential renewable sources which can be applied for dyeing of wool, silk and cotton. But due to non-availability of sufficient natural dyes sources, repeatability and cost the use of natural dyes for commercial dyeing application has declined considerably. But by correctly identifying the natural dye sources, the natural dye can be utilized by industries on a commercial scale. For the identification of the potential dye sources, a quantification technique has been generated. Based on the quantification technique the identified potential dye sources can be evaluated for commercial suitability. Two potential natural dyes were used as source of colour extraction. Dyeing of cotton fabric with natural colorant has been done. The dyeing process was carried out with different mordant. Wash fastness of dyed sample has been evaluated. The wash fastness, time estimation and water required were compared among the two natural dyes sources and it is prioritized for commercial application.
\end{abstract}

Keywords: - Natural Dyes, Mordant, Wash Fastness, Time and Water estimation, Commercial scale

\section{INTRODUCTION}

Textile materials are coloured for value addition, looks and fulfilling the desires of the customers. Anciently, this purpose of colouring textile was initiated using natural sources, until synthetic dyes were invented. Almost all the synthetic dyes are made from petrochemical sources through hazardous chemical processes and pose threat to the environment. However, worldwide environment protection and safety renewed the interest of the people on natural products like natural fibres and natural dyes. The natural dye is not commercially used in the industry as it has limitations such as poor color fastness, practical difficulty in repeatability, seasonability and high cost (Ashis Kumar Samanta and Adwaita Konar 2011).

In this paper, based on the literature survey the identified potential dye sources Marigold and Onion peel are evaluated for commercial suitability. The selection of potential natural dye source is done based on the quantification technique, which involves variable parameters which influence the dyeing process. The cotton fabric has been chosen for dyeing. The various parametrs that should be taken into account are

- Availability of dye material round the year.

- Time needed to grow the plant material or to yield the dye

- Colour yield

- Dye concentration needed

- Wash fastness

- Light fastness

- Rub fastness

- Fastness to perspiration

- Dye bath temperature

- Dyeing time
- Need for mordant and its concentration

- Waste generated

- Quantity of liquid effluent

- Material cost

- Processing cost

- Use of the dye source for other application

\section{DESIGN OF EVALUATION METHOD}

For identification and selection of the potential dye sources, a commercial dyeability index has been generated. This commercial dyeability is based on the variable parameters which influence the dyeing process. The parameters are fastness property, K/S value, extraction temperature, extraction and dyeing time, hazard factor, hazardous materials, availability of plant source, seasonability, wastewater, solid and liquid waste, cost factor and the application factor. The values to be assigned for the evaluation are tabulated in the table 1 to table 8 .

\section{Commercial Dyeability Index}

The generated commercial dyeability index is:

Commercial dye ability index $=$

$\{[$ Source factor $+3 *$ (Fastness + Colour Yield $)] /[$ Dyeing Factor +Hazard Factor + cost factor $]\}$ + Application factor 


\begin{tabular}{|l|l|l|}
\hline Source factor & $=$ & $\begin{array}{l}\text { [Availability + Time for the } \\
\text { Plant to grow ] }\end{array}$ \\
\hline Fastness & $=$ & $\begin{array}{l}{[2 \text { [Wash fastness ]+light }} \\
\text { Fastness + Rub fastness } \\
+ \text { perspiration fastness }]\end{array}$ \\
\hline K/s & $=$ & {$[$ Color yield] } \\
\hline dyeing factor & $=$ & $\begin{array}{l}{[\text { Dyeing temperature + }} \\
\text { Dyeing time + mordant } \\
\text { Concentration + dye content }]\end{array}$ \\
\hline Hazard factor & $=$ & $\begin{array}{l}{[\text { Toxicity + solid waste }} \\
\text { Generated+ liquid waste } \\
\text { generated ] }\end{array}$ \\
\hline Cost factor & $=$ & $\begin{array}{l}{[\text { Material cost + processing }} \\
\text { Cost ] }\end{array}$ \\
\hline $\begin{array}{l}\text { Application } \\
\text { factor }\end{array}$ & $=$ & $\begin{array}{l}{[\text { Use of dye source in other }} \\
\text { useful application] }\end{array}$ \\
\hline
\end{tabular}

First the commercial dyeability index is calculated for selected dye source and then its value is used to look up in the commercial dyeability index value given in Table 1 . The larger the value the commercial dyeability index, the more suitable it becomes for commercial application.

Table 1: Availability

\begin{tabular}{|l|l|l|l|}
\hline Availability & $\begin{array}{l}\text { Once in 4 } \\
\text { months }\end{array}$ & $\begin{array}{l}\text { Once in 6 } \\
\text { months }\end{array}$ & $\begin{array}{l}\text { Once in 12 } \\
\text { months }\end{array}$ \\
\hline Value & 3 & 2 & 1 \\
\hline
\end{tabular}

Table 2 :Time for the Plant to grow

\begin{tabular}{|l|l|l|l|}
\hline $\begin{array}{l}\text { Time for the } \\
\text { Plant to } \\
\text { grow }\end{array}$ & 1 year & 6 months & 4 months \\
\hline Value & 1 & 2 & 3 \\
\hline
\end{tabular}

Table 3: Fastness property

\begin{tabular}{|l|l|l|l|}
\hline $\begin{array}{l}\text { Fastness } \\
\text { property }\end{array}$ & Less than 3 & $3-4$ & $4-5$ \\
\hline value & 1 & 2 & 3 \\
\hline
\end{tabular}

Table 4: Dyeing temperature

\begin{tabular}{|l|ll|ll|l|}
\hline $\begin{array}{l}\text { Dyeing } \\
\text { temperature }\end{array}$ & $40-50$ & ${ }^{0} \mathrm{C}$ & $50-70$ & ${ }^{0} \mathrm{C}$ & $\begin{array}{l}\text { Above 70 } \\
\mathrm{C}\end{array}$ \\
\hline value & 3 & & 2 & 1 & \\
\hline
\end{tabular}

Table 5: Dyeing time

\begin{tabular}{|l|l|l|l|}
\hline Dyeing time & $\begin{array}{l}\text { Less than 30 } \\
\text { minutes }\end{array}$ & $\begin{array}{l}30-45 \\
\text { minutes }\end{array}$ & $\begin{array}{l}\text { Above 45 } \\
\text { minutes }\end{array}$ \\
\hline value & 3 & 2 & 1 \\
\hline
\end{tabular}

Table 6: Hazard factor

\begin{tabular}{|l|l|l|l|}
\hline $\begin{array}{l}\text { Hazard } \\
\text { factor }\end{array}$ & $\begin{array}{l}\text { Presence of } \\
\text { toxic waste, } \\
\text { solid waste } \\
\text { and liquid } \\
\text { effluent }\end{array}$ & $\begin{array}{l}\text { No toxic } \\
\text { waste Only liquid } \\
\text { effluent }\end{array}$ \\
\hline value & 3 & 2 & 1 \\
\hline
\end{tabular}

Table 7 : Cost factor

\begin{tabular}{|l|l|l|l|}
\hline Cost factor & Less costly & Medium & $\begin{array}{l}\text { Considerable } \\
\text { cost }\end{array}$ \\
\hline value & 1 & 2 & 3 \\
\hline
\end{tabular}

Table 8: Application factor

\begin{tabular}{|l|l|l|l|}
\hline $\begin{array}{l}\text { Application } \\
\text { factor }\end{array}$ & $\begin{array}{l}\text { Can be used } \\
\text { for Textile }, \\
\text { food and } \\
\text { cosmetic } \\
\text { applications }\end{array}$ & $\begin{array}{l}\text { Only used } \\
\text { for } \\
\text { Textile and } \\
\text { cosmetic } \\
\text { applications }\end{array}$ & $\begin{array}{l}\text { Only suitable } \\
\text { for fextile } \\
\text { applications }\end{array}$ \\
\hline value & 1 & 2 & 3 \\
\hline
\end{tabular}

Table 9: Commercial Dyeability Index Value

\begin{tabular}{|c|c|c|c|}
\hline $\begin{array}{l}\text { Commer } \\
\text { cial } \\
\text { Dyeabili } \\
\text { ty Index }\end{array}$ & $\begin{array}{l}\text { Not } \\
\text { Applicable } \\
\text { For } \\
\text { Commercial } \\
\text { Application }\end{array}$ & $\begin{array}{l}\text { Can Be } \\
\text { Considered }\end{array}$ & $\begin{array}{l}\text { Suitable For } \\
\text { Commercial } \\
\text { Application }\end{array}$ \\
\hline Value & below 2 & $2-4$ & Above 4 \\
\hline
\end{tabular}

\section{PRETREATMENT OF FABRIC}

The experiments were conducted for dye extraction, dyeing and wash fastness properties using literature support. Desizing is done in order to remove the size from the warp yarns of the woven fabrics. It is done by soaking the cotton fabric in $0.5 \%$ of concentrated Sulphuric acid in 1:20 liquor ratio for 12 hour. (Kulkarni S.S, Gokhale A.V, Bodake U.M, Pathade G.R, 2011).

Scouring is done to remove dirt, wax and oil. The scouring is done by dipping the fabric in a distilled water (1:20) containing the mixture, Sodium hydroxide $(5 \%)$, Sodium carbonate $(1 \%)$, and Soap oil $(1 \%)$ and kept at $100^{\circ} \mathrm{C}$ for 4 hour. (Kulkarni S.S, Gokhale A.V, Bodake U.M, Pathade G.R, 2011).

\section{DYEING WITH MARIGOLD}

Marigold is annual plant and perennial plant, mostly herbaceous plant in the sunflower family Asteraceae. It bears yellowish orange flowers in abundance during the flowering season which lasts for more then 6-8 months.

For dye extraction, the Marigold petals were dried in shade and powdered. The powdered flowers petals of Marigold (50 g) was dissolved in $500 \mathrm{ml}$ of distilled water and heated for 
one hour at $100^{\circ} \mathrm{C}$ (Padma.S Vankar, Rakhi Shankar,Samudrika, 2009 ). The extract was filtered to obtain a yellowish brown dye solution.

For mordanting, accurately weighed cotton samples were pre-mordanted with Alum and Copper Sulphate. The mordant $2 \%$ (owf) was dissolved in water to make a liquor ratio 1:40 and heated at $80^{\circ} \mathrm{C}$ for a period of 1 hour (Padma.S Vankar, Rakhi Shankar, Samudrika, 2009).

Then the pre-treated samples are immersed in dye bath for 1 hour at a temperature range of $70-80{ }^{\circ} \mathrm{C}$, keeping M: L ratio as 1:50 (Padma.S Vankar, Rakhi Shankar, Samudrika, 2009).

\section{DYEING WITH ONION PEEL}

The onion is used as a vegetable and is most frequently a biennial plant or a perennial plant. But the skin of the onion which is inedible can be used as dyes.

For dye extraction, the unused onion peel was collected and $30 \mathrm{~g}$ of onion peel was dried in shade and powdered.The outer most onion scales which was powdered $(20 \mathrm{~g})$ was boiled in 1 litre of distilled water for 1 hour. (Ferial M. Tera, Khaled E. Elnagar, S.M Mohamed, 2012). Then it was filtered to obtain a reddish brown dye solution.

For pre-mordanting, the fabric was pre- mordanted by soaking separately for 12 hours in $(5 \mathrm{~g} / \mathrm{L})$ for Alum and $(1.6 \mathrm{~g} / \mathrm{L})$ for Potassium dichromate. And the post mordanting was carried out separately in a solution of Copper sulphate of $(1.2 \mathrm{~g} / \mathrm{L})$ and $(1.6 \mathrm{~g} / \mathrm{L})$ for Ferrous sulphate in distilled water, the dyed fabric was immersed in the solution of liquor ratio (LR) (1:50), then temperature was raised to $80^{\circ} \mathrm{C}$ and kept for 1 hour. (Ferial M.Tera, Khaled E.Elnagar, S.M Mohamed, 2012).

The pre-treated samples are immersed in dye bath containing extracted solution of natural dye for 1 hour at a temperature range of $80^{\circ} \mathrm{C}$, keeping M: L ratio as 1:40 (Ferial M.Tera, Khaled E. Elnagar, S.M Mohamed, 2012).

\section{WASH FASTNESS}

The wash fastness is the ability of fabrics to retain the dyes used to color them, when subjected to washing. Preparation of soap solution is done by dissolving $0.2 \mathrm{~g}$ of soap powder into $20 \mathrm{ml}$ of water. Place the dyed fabrics in solution mixture and keeps it for 2 minutes. Then the sample is dried and checked for color change. The number of wash is continued still no color is detected in the water during washing.

\section{PROCESSING TIME AND WATER ESTIMATION}

The time required for each process involved during dyeing for each natural dye source is 5 hours and 10 minutes. The total water required in the each phase of the dyeing process is estimated and it was found to be ranging from 1000- 4000 $\mathrm{ml}$ of water.

The wash fastness, time estimation and water required were compared among the two natural dyes sources and it is prioritized. The prioritized potential dye sources are listed in the order in the table 10.

Table 10: Priortised dye sources

\begin{tabular}{|l|l|l|}
\hline S.No & Dye Source & Mordant Used \\
\hline 1 & Onion & Alum \\
\hline 2 & Onion & Copper sulphate \\
\hline 3 & Onion & Potassium di chromate \\
\hline 4 & Onion & Ferrous sulphate \\
\hline 5 & Marigold & Copper sulphate \\
\hline 9 & Marigold & Alum \\
\hline
\end{tabular}

\section{RESULT AND DISCUSSION}

The identified potential natural dye sources namely, Onion peel, and Marigold have been selected and dyeing process have been done.

Dyed fabric are subjected to wash fastness test, and it can be observed that onion dyed fabric stops fading after the second wash, whereas for Marigold, color either fades or the color bleeds in the water at third wash or after third wash. So the cloth dyed with Onion peel was found to have better fastness than Marigold.

The color shades obtained are more soothing and uniform for the fabric dyed with Onion peel and Marigold. In case of time and water required, all the two natural dyes have equal expenditure for time and water required. Based on the commercial dyeability index, wash fastness, cost and time estimation the dye sources with different mordants have been prioritized, which is shown in table 10. And Onion peels as natural dye source has showed good result and it is found to be suitable for large scale application.

\section{CONCLUSION}

In this paper, commercial dyeability index for selection of natural dyes for commercial application has been evolved. A comparison of potential dye sources for commercial application has been done. Based on the commercial dyeability index, wash fastness, cost and time estimation the dye sources with different mordants can be prioritized and used for commercial application with good success.

\section{REFERENCES}

[1] Ferial M.Tera, Khaled E. Elnagar, S. M. Mohamed, Journal of textile and apparel, technology and management, Volume 7, Issue 3, Spring2012.

[2] Kulkarni S.S, Gokhale A.V, Bodake U.M, Pathade G.R., Universal Journal of Environmental Research and Technology, Volume1, Issue 2: 135-139, (2007 ). 
[3] Padma.S Vankar, Rakhi Shankar, Samudrika, Journal of textile and apparel, technology and management, Volume 6, Issue 1, Spring2009.

[4] Dr.PadmaS.Vankar, Handbook On Natural Dyes For Industrial Applications, 2007.

[5] Ashis Kumar Samanta and Adwaita Konar, inTech2011, DOI: 10.5772/21341. Available from: https://www.intechopen.com/books/naturaldyes/dyeing-of-textiles-with-natural-dyes. 